\title{
Acetate supply and utilization by the tissues of sheep in vivo
}

\author{
BY D. W. PETHICK, * D. B. LINDSAY, P. J. BARKER AND \\ A. J. NORTHROP \\ Biochemistry Department, ARC Institute of Animal Physiology, Babraham, \\ Cambridge CB2 4AT
}

\section{(Received 19 January 1981 - Accepted 10 February 1981)}

1. The supply and utilisation of acetate has been estimated simultaneously in the whole animal and tissues of sheep using a combination of isotope-dilution and arteriovenous-difference techniques. Animals were made alloxandiabetic and acetate metabolism was compared when stabilized to normal metabolite levels with insulin (ITA sheep) and when food and insulin had teen withdrawn for $36 \mathrm{~h}$ (fasted, diabetic sheep).

2. Acetate was simultaneously produced and utilized by all tissues. The exogenous (or gut) supply of acetate was the most important determinant of circulating acetate level. Endogenous acetate was produced mainly in the liver; 77 and $94 \%$ in fasted, diabetic and ITA sheep respectively. The production of endogenous acetate remained fairly constant and was not related to ketogenesis, which supports the idea that circulating acetate is largely a product of fermentation. The liver, gut and muscle utilized 17,25 and $54 \%$ respectively ( $96 \%$ total) of the acetate entry rate in ITA sheep; a similar percentage utilization was found in fasted, diabetic sheep.

3. Acetate is largely oxidized to carbon dioxide in the gut and muscles of sheep and may account for $30-40 \%$ of their oxidative metabolism. This figure is similar to that for the whole animal. The total acetate taken up by the liver could account for $30 \%$ of the oxygen consumption; however, the liver may not directly oxidize all the utilized acetate.

4. The over-all conclusion frorn this study is that acetate is largely of dietary origin and the major factor determining its rate of utilization is the arterial concentration.

Acetate is a significant metabolite of the sheep as a substrate both for oxidation (Annison \& Armstrong, 1970) and fat synthesis (Ballard et al. 1969). For nearly 20 years it has been known that circulating acetate is composed of alimentary (exogenous) and tissue (endogenous) components (.Annison \& Lindsay, 1961; Annison \& White, 1962). Of the acetate entering the circulation only part (70\% in fed, $30 \%$ in starved sheep) is believed to come from the gut (Annison \& White, 1962; Bergman \& Wolff, 1971). Consequently it is thought that acetate concentration and entry rate have limited nutritional significance (Annison et al. 1967; Lindsay, 1978). Acetate synthesis by tissues is thought to be controlled largely by the supply of non-esterified long-chain fatty acids (NEFA) (Annison \& White, 1962; Costa et al. 1976) since the perfused rat liver can form large quantities of both ketones and acetate from fatty acids (Seufert et al. 1974).

The tissues both supplying and utilizing acetate have not been well studied in the whole animal. Such experiments must allow for a simultaneous uptake and release of acetate and this has only been satisfied in experiments by Bergman \& Wolff (1971). In their work the portal drained viscera (gut) cf sheep both utilized and released acetate while the liver did not apparently metabolize acetate. The results for hepatic metabolism were equivocal due to a large variability and more recently a net hepatic utilization of acetate has been observed (Thompson $e t$ al. 1975). Metabolism of acetate by sheep muscle using a similar technique to that of Bergman \& Wolff (1971) has not been reported.

In this work we planned to partition the production and utilization of acetate for the whole animal between the gut, liver and muscle. Acetate metabolism in alloxan-treated insulin-stabilized and fasted, diabetic sheep was also compared so that the partition of acetate supply in normal and extreme rates of NEFA supply to the tissues could be made.

\footnotetext{
- Present address: Schcol of Veterinary Studies, Murdoch University, W. Australia.
} 
This also permitted a ready comparison between the quantitative and qualitative changes in hepatic metabolism of acetate and ketones in relatively normal and ketotic sheep. Finally the partition of acetate utilization between the tissues for oxidative and other reactions is reported.

\section{MATERIALS AND METHODS}

\section{Animals}

Clun Forest ewes (4-year-old; mean body-weight $54 \mathrm{~kg}$ ) were given a daily ration of $1 \mathrm{~kg}$ chopped hay ( $500 \mathrm{~g}$ lucerne (Medicago sativa); $500 \mathrm{~g}$ cocksfoot (Dactylis glomerata)) and $100 \mathrm{~g}$ rolled oats as twelve equal-sized portions at $2 \mathrm{~h}$ intervals to produce an approximately constant rate of fermentation within the rumen. The ration was adequate to maintain body-weight. Apparently digestible energy content was estimated at approximately $9.8 \mathrm{MJ} / \mathrm{kg}$ (MAFF, 1976). Water was freely available at all times.

Five of the sheep were surgically prepared with indwelling portal, hepatic and mesenteric vein catheters much as described by Katz \& Bergman (1969a) and carotid arterial and recurrent tarsal vein catheters as described by Domanski et al. (1974). The recurrent tarsal vein was cannulated under local anaesthesia $12-20 \mathrm{~h}$ before experimentation while the splanchnic and arterial catheters were implanted at least 4 weeks earlier. All catheters were maintained patent by daily heparinized saline $(9 \mathrm{~g}$ sodium chloride $/ \mathrm{l} ; 100 \mathrm{mU} / \mathrm{ml})$ administration. Sheep were made alloxan-diabetic 1 week after surgery by the intrajugular administration of alloxan ( $40 \mathrm{mg} / \mathrm{kg}$ body-weight; Sigma Chemical Co., St Louis, USA). Once diabetes was confirmed (glycosuria and ketonuria) animals designated ITA sheep were maintained with daily subcutaneous injections of approximately $40 \mathrm{U}$ Lente insulin (Wellcome Foundation Ltd, London). This resulted in nearly-normal circulating concentrations of metabolites (see Table 1). Apart from a moderate hyperglycaemia such animals have been maintained for at least 12 months. Insulin and food withdrawal for $36 \mathrm{~h}$ were used to produce markedly hyperglycaemic and ketonaemic diabetic sheep (fasted, diabetic sheep) see Table 1.

\section{Experimental}

On the day of the experiment the sheep under study (either ITA or diabetic) was placed at approximately 09.00 hours in an open-circuit calorimeter (Neill et al. 1979) the head being enclosed by a hood. Sheep had been previously acclimatized by at least six, $8 \mathrm{~h}$ periods in the calorimeter and ate and drank normally. The calorimeter allowed measurement of respiratory gas exchange and ${ }^{14} \mathrm{CO}_{2}$ concentration in expired air. At 09.30 hours an intrajugular infusion of 100-200 $\mu \mathrm{Ci}\left[\mathrm{U}-{ }^{14} \mathrm{C}\right]$ acetate (The Radiochemical Centre, Amersham, Bucks; $40-60 \mathrm{mCi} / \mathrm{mmol})$ and $10000 \mathrm{U}$ heparin in sterile saline solution $(0.5 \mathrm{ml} / \mathrm{min})$ was commenced and lasted for $5 \mathrm{~h}$. Simultaneous samples were withdrawn from portal, hepatic and recurrent tarsal vein and carotid arterial circulations (using a Desaga multichannel pump; Camlab Ltd, Cambridge) at hourly intervals during the infusion and collected on ice. Heparin infusion was necessary to prevent thrombi forming in these sampling lines. Whole blood was used for determination of specific radioactivity of acetate and concentrations of volatile fatty acid (VFA), ketone body and glucose. Ten, hourly samples were taken from all circulations for the measurement of specific radioactivity of blood $\mathrm{CO}_{2}$ and $\mathrm{CO}_{2}$ and oxygen concentrations. Blood flow was measured after the infusion of [U-14C]acetate. Not more than $200 \mathrm{ml}$ blood was removed per experiment.

\section{Blood flow}

Blood flow in the splanchnic area was measured as described by Katz \& Bergman (1969 b). The extraction of an intrajugularly-infused sulphobromophthalein sodium solution (BSP; Koch-Light Laboratories Ltd, Colnbrook) by the liver was used to measure total hepatic 
blood flow while dilution of an intremesenterically infused $p$-aminohippuric acid solution (PAH; Koch-Light Laboratories Ltd, Colnbrook) was used to measure portal and hepatic vein and hepatic arterial blood flows. Consistent results with the latter method could not be obtained and some apparently negative hepatic arterial blood flows were measured, despite similar estimates for total hepatic flow using BSP and PAH.

The measurement of total hepatic blood flow using BSP is not susceptible to mixing problems, and if hepatic flow is taken as unity then portal flow can be assumed as 0.8 and hepatic arterial flow as 0.2. (Katz \& Bergman, 1969b; Thompson et al. 1975; Paterson \& Harrison, 1972). All splarchnic measurements reported here were obtained in this way. Muscle blood flow was measured by the tissue saturation technique using ${ }^{3} \mathrm{H}_{2} \mathrm{O}$ as a marker as described by Pappenheirner \& Setchell (1972) for measuring blood flow in the sheep brain.

\section{Metabolite determination}

Acetate. Acetate concentration was determined using a gas-liquid chromatographic (GLC) technique. The acid-volatilis components of blood were concentrated by 'freeze-transferring' acidified blood. Blood $(1 \mathrm{ml})$, acid $(1 \mathrm{ml}$ perchloric acid; $0.36 \mathrm{M})$, water $(1 \mathrm{ml})$ and an internal standard (200 and $800 \mathrm{nmol}$ isobutyric acid for fasted and fed sheep respectively) were mixed and then shell-frozen in a $50 \mathrm{ml}$ Quickfit flask using liquid nitrogen. The flask was connected by a ' $U$ ' piece with a two-way tap to a $10 \mathrm{ml}$ Quickfit test-tube containing $0.25 \mathrm{ml}$ frozen $\mathrm{M}$-sodium hydroxide. The whole system was evacuated and the test-tube placed in liquid $\mathrm{N}_{2}$, resulting in complete sublimation of plasma water and acid-volatile components within $2 \mathrm{~h}$. Once thawed the sample was dried on a rotary evaporator $\left(45^{\circ}\right)$ and then left under vacuum over phosphorous pentoxide overnight. For analysis the sample was acidified with $200 \mu 13$ k-phosphoric acid. VFA concentration was measured by GLC on a $2 \mathrm{~m} \times 4 \mathrm{~mm}$ glass column of $200 \mathrm{~g}$ neopentyl glycol adipate (Phase Separations Ltd, Clwyd) and $20 \mathrm{~g}$ phosphoric acid/kg Universal support 60/85 mesh (Phase Separations Ltd). The column was housed in a Pye 104 chromatograph and samples were injected with an S4 Autojector (Pye Unicam Ltd, Cambridge). Peak areas were computed by a Pye Unicam DP88 integrator. Recovery of internal standard was 85-95\% complete and one set of isobutyric acid-free samples was always run with each analysis to allow for endogenous isobutyrate in blood. Endogenous isobutyrate concentration was always less than $1 \%$ of the internal standard (i.e. approximately $5 \mu \mathrm{M}$ ) except for portal blood where it was approximately $1-2 \%$ of the internal standard $(10-20 \mu \mathrm{M})$. Radioactivity was measured by liquid-scintillation counting techniques using a part of the remaining acid concentrate. For specific radioactivity determinations the radioactivity was assumed to be found in acetic acid only.

Ketones. Blood D(-)3-hydroxybutyrate (3-HB) and acetoacetate (AcAc) were measured on neutralized perchloric acid filtrates of blood by the enzymic method of Williamson et al. (1962).

Glucose. Glucose was determined enzymatically on perchloric acid filtrates of blood by the method of Werner et al. (1970) using a Boehringer Kit (The Boehringer Corporation (London) Ltd).

Blood gases. Blood $\mathrm{CO}_{2}$ concentration and specific radioactivity were determined by the method of Hinks et al. (1965). Recovery of standard [U- $\left.{ }^{14} \mathrm{C}\right]$ acetate in the determination of the specific radioactivity of $\mathrm{CO}_{2}$ was less than $2 \%$. The concentration of $\mathrm{O}_{2}$ was determined oximetrically using a model 182 co-oximeter (Instrumentation Laboratories, Lexington, Mass., USA).

Blood flow markers. Plasina BSP was determined by a modification of the method described by Bradley et al. (1945) so that only $200 \mu 1$ plasma was needed for analysis. PAH was estimated as described by Katz \& Bergman (1969b). 
Radioactivity. Both ${ }^{3} \mathrm{H}_{2} \mathrm{O},\left[\mathrm{U}-{ }^{14} \mathrm{C}\right]$ acetate and ${ }^{14} \mathrm{CO}_{2}$ radioactivity were measured by aqueous liquid-scintillation counting techniques using an Analytic 92 liquid-scintillation spectrometer (G. D. Searle \& Co., Chicago, Illinois, USA). Counting efficiency was $86 \%$ for ${ }^{14} \mathrm{C}$ and $35 \%$ for ${ }^{3} \mathrm{H}$ and was checked routinely by an external-standard, channels-ratio method and verified by internal standardization using standard $n-\left[1-{ }^{14} \mathrm{C}\right]$ hexadecane (The Radiochemical Centre).

\section{Calculations}

Some of the calculations are similar to those used by Bergman \& Wolff (1971).

Whole animal.

$$
\text { (a) entry rate }(\mathrm{mmol} / \mathrm{h})=\frac{I}{\text { acetate } S R A},
$$

where $I$ is the infusion rate of $\left[U-{ }^{14} \mathrm{C}\right]$ acetate (disintegrations/min per h) and SRA is the mean arterial specific radioactivity (disintegrations per $\mu \mathrm{mol}$ );

(b) the proportion of respiratory $\mathrm{CO}_{2}$ derived from acetate

$$
\text { ('equilibrium calculation') }=\frac{\text { terminal expired } \mathrm{CO}_{2} S R A}{\text { plateau arterial acetate } S R A \text { (during infusion) }}
$$

where $S R A$ were expressed as disintegrations/min per mAtom $\mathrm{C}$. Terminal expired air $\mathrm{CO}_{2}$ $S R A$ was obtained as the limiting value from a single exponential analysis of specific radioactivity $v$. time;

(c) the proportion of respiratory $\mathrm{CO}_{2}$ derived from acetate

$$
\text { ('area calculation') }=\frac{\text { mean expired } \mathrm{CO}_{2} S R A}{\text { mean arterial acetate } S R A},
$$

where $S R A$ were expressed as disintegrations/min per mAtom. Mean values were calculated from the period during and after infusion of $\left[\mathrm{U}-{ }^{14} \mathrm{C}\right]$ acetate. Fig. 1 illustrates the difference between calculations $b$ and $c$ as applied to tissue oxidation; the same approach has been used in application to acetate oxidation by the whole animal.

Tissues. The net utilization of acetate or ketones $(\mathrm{mmol} / \mathrm{h})=([A]-[V]) B F$ where $[A]$ and $[V]$ are the concentrations in arterial and venous circulations $(\mathrm{mmol} / \mathrm{ml})$ and $B F$ is the tissue blood flow $(\mathrm{ml} / \mathrm{h})$. Gross utilization of acetate $(\mathrm{mmol} / \mathrm{h})$ is

$$
\frac{\left(\left[{ }^{14} \mathrm{C}_{\mathrm{A}}\right]-\left[{ }^{14} \mathrm{C}_{\mathrm{V}}\right]\right)}{\text { Acetate } S_{A}}+B F
$$

where $\left[{ }^{14} \mathrm{C}_{\mathrm{A}}\right],\left[{ }^{14} \mathrm{C}_{\mathrm{V}}\right]$ are the amounts of radioactive blood acetate (disintegrations/ $\min$ per $\mathrm{ml}$ ) in arterial and venous circulations respectively. Acetate $S_{A}$ is the arterial specific radioactivity (disintegrations $/ \mathrm{min}$ per $\mathrm{mmol}$ ); acetate production $(\mathrm{mmol} / \mathrm{h}$ ) = gross utilization - net utilization.

The maximum contribution of acetate to tissue $\mathrm{O}_{2}$ consumption is:

$$
\frac{([A]-[V]) \text { acetate } \times 2}{([A]-[V]) \mathrm{O}_{2}}
$$

where acetate and $\mathrm{O}_{2}$ concentrations are expressed as $\mu \mathrm{mol} / \mathrm{ml}$.

Direct oxidation of acetate to $\mathrm{CO}_{2}$ has been determined by measuring the production of ${ }^{14} \mathrm{CO}_{2}$ from utilized [U- ${ }^{14} \mathrm{C}$ ]acetate. Total ${ }^{14} \mathrm{CO}_{2}$ excretion can be measured from the area under the arteriovenous ${ }^{14} \mathrm{CO}_{2}$ difference curve during and after the infusion of [U-14 C]acetate: alternatively the ${ }^{14} \mathrm{CO}_{2}$ excretion can be assumed to have reached a steady-state value within the infusion time (see Fig. 1). These two methods will be referred to as area and equilibrium calculations respectively. The $\mathrm{CO}_{2}$ released by the gut is of both metabolic (tissue) and fermentative origin (McCrae et al. 1978). In the present study the 


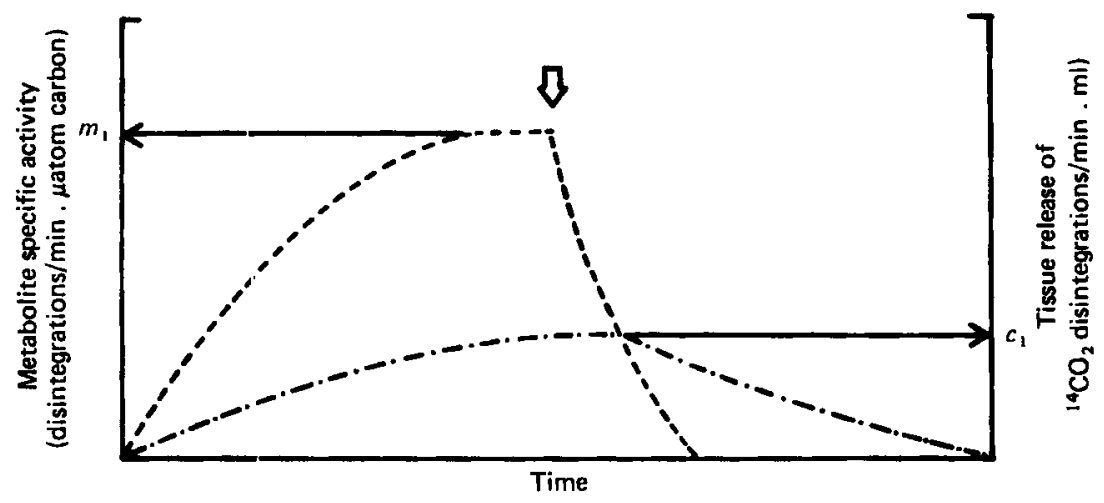

Fig. 1. A schematic representation of metabolite specific radioactivity (SR; - - - ) and tissue release of ${ }^{14} \mathrm{CO}_{2}(\cdot \cdot-\cdot \cdot \cdot \cdot)$ during and following the constant infusion of ${ }^{14} \mathrm{C}$-labelled metabolite. $\downarrow$ Infusion off. The proportion of $\mathrm{CO}_{2}$ proc uced by the tissue which is derived from the infused ${ }^{14} \mathrm{C}$-labelled metabolite can be calculated in two ways: (1) equilibrium calculation:

$$
\text { proportion }=\frac{C_{1}}{M_{1}} \frac{1}{(V-A) \mathrm{CO}_{2}},
$$

where $C_{1}$ is the estimated terminal ${ }^{14} \mathrm{CO}_{2}$ released (disintegrations/min per $\mathrm{ml}$ ) at end of infusion, $M_{1}$ is the estimated terminal met.1bolite SR (disintegrations $/ \mathrm{min}$ per $\mu$ atom $\mathrm{C}$ ) and $V$ and $A$ are tissue venous and arterial blood $\mathrm{CO}_{2}$ concentrations (mM); (2) area calculation:

$$
\text { proportion }=\frac{C_{a}}{M_{a}} \times \frac{1}{(V-A) \mathrm{CO}_{2}}
$$

where $C_{\alpha}$ is the average ${ }^{14} \mathrm{CO}_{2}$ released (disintegrations/min per $\mathrm{ml}$ ) over whole period studied, $M_{a}$ is average metabolite SR (disintegrations/min per $\mu$ atom $\mathrm{C}$ ) over whole period studied and $V$ and $A$ are tissue venous and arterial blcod $\mathrm{CO}_{2}$ concentrations (mM).

gut respiratory quotient $(\mathrm{R}(2)$ was $1 \cdot 47$. It has been assumed in the previously-mentioned calculation (Fig. 1) for the gut of ITA sheep that the tissue arteriovenous difference of $\mathrm{CO}_{2}$ is equal to that of $\mathrm{O}_{2}$ (i.e. $\mathrm{RQ} 1$ ) which is similar to that found in muscle (RQ $0.94 \pm 0 \cdot 11$ ). The best estimate of the specific radioactivity of precursor acetate for oxidation calculations would be intramitochondrial acetate. Since this is not accessible, the venous effluent specific radioactivity of acetate is ta.ken as the best approximation to this.

The proportion of utilized acetate directly oxidized is calculated as:

$$
\frac{\text { net output } \mathrm{CO}_{2} \times \text { proportion net } \mathrm{CO}_{2} \text { output derived from acetate }}{\text { gross utilization of acetate }}
$$

both $\mathrm{CO}_{2}$ and acetate being; expressed per mAtom $\mathrm{C}$.

In all calculations, $V$ is the venous blood from portal, hepatic and recurrent tarsal vein for calculations of gut, liver and muscle metabolism respectively. A further modification was made to estimate liver metabolism; $A$, arterial blood, was replaced by a weighted mean of arterial and portal vein $(P V)$ circulations $(0.2 A+0.8 P V)$ to allow for portal vein and hepatic arterial blood flow.

In calculating the total contribution of muscle to acetate uptake and output, we have assumed that the muscle stuclied is representative of the total muscle mass and this has been taken as $25 \%$ of body-weight. In seven dissections of mature Clun Forest Sheep in this Institute, F. A. Harrison (personal communication) has determined muscle mass to be $25 \cdot 3 \pm 0 \cdot 86 \%$ body-weight. l'alsson \& Verges (1952) reported a value of $24 \cdot 2 \%$. 


\section{RESULTS}

\section{Effect of diabetes on metabolite levels}

The concentration of glucose, acetate and ketones in normal and ITA ewes is shown in Table 1. ITA ewes were moderately hyperglycaemic, but all other metabolites were similar to those found in normal ewes eating the same diet suggesting that fatty acid metabolism was similar in ITA and normal ewes. To normalize the glucose concentration requires a much higher dose of insulin, probably in order to match the normal high insulin concentration in portal blood. This would have resulted in hypernormal peripheral insulin concentration. Withdrawal of food and insulin resulted in expected diabetic changes. Food withdrawal would have been a relatively minor component of the ketonaemia since fasting two normal ewes for $3 \mathrm{~d}$ resulted in mean 3-HB and AcAc concentrations of only 0.5 and $0.1 \mathrm{~mm}$ respectively.

\section{Concentration of specific radioactivity of acetate and tissue blood flow}

Combined measurements of whole animal and tissue metabolism using isotope-dilution and arteriovenous-difference techniques ideally rely on steady-state conditions, that is, constant circulating metabolites, specific radioactivities and tissue blood flows (Zierler, 1961). Range of variability in circulating acetate concentration and specific radioactivity of acetate for an ITA sheep (Expt. no. 99) is shown in Figs 2 and 3; both measurements were reasonably stable. Hepatic blood flow was always fairly constant during the $90 \mathrm{~min}$ determination period so that the standard error was less than $5 \%$ of the mean. It has been shown in separate experiments in this laboratory that if muscle blood flow $(1 / \mathrm{min} \mathrm{per} \mathrm{kg}$ ) is $y$ and muscle arteriovenous difference for $\mathrm{O}_{2}(\mu \mathrm{mol} / \mathrm{ml})$ is $x$ then $y=-0.038+0.32\left(r^{2}\right.$ $\left.0.6 ; F_{33}^{1} 17.5 ; P<0.001\right)$. That is, $\mathrm{O}_{2}^{-}$utilization by resting muscle is fairly constant and not dependent on blood flow. Consequently the relatively stable $\mathrm{O}_{2}$ arteriovenous difference for muscle shown in Fig. 2 is indicative of fairly stable muscle blood flow.

The range of values for concentration, specific radioactivity, infusion rate and blood flow are shown in Tables 2 and 3 for all animals. These results have been used to calculate the utilization and production rates summarized in Table 4.

\section{Utilization and production of acetate}

Circulating acetate appears to be dominated by the production of acetate by the gut since arterial levels declined by $84 \%$ in diabetic animals, a fall similar in magnitude to the decline in absorption (gross gut production). In the fed sheep gross acetate release in the portal vein represented $25 \%$ of the estimated apparently digestible energy (DE) intake. Total organic acids (excluding lactate) appearing in the portal vein (net production (mean $\pm \mathrm{SE}$ ) in $\mathrm{mmol} / \mathrm{h}$ of propionate, isobutyrate, butyrate, isovalerate, valerate, 3-HB and AcAc was $34 \cdot 1 \pm 8,1 \cdot 0 \pm 0.05,4 \cdot 3 \pm 1,1 \cdot 4 \pm 0 \cdot 1,0 \cdot 5 \pm 0 \cdot 03,11 \cdot 1 \pm 3 \cdot 2$ and $4 \cdot 1 \pm 0.4$ respectively) represented $49 \%$ of the DE intake (66\% of the energy expenditure of the ITA sheep).

Acetate is produced in other tissues and the sum of the rate of production in gut, liver and muscle, accounts for $114 \%$ of the total acetate entry. Such a value reflects the inherent errors in using the techniques of this study, which may be as large as $20 \%$ (Bergman, 1975). Additional errors may arise from the assumption that the hepatic artery supplies $20 \%$ of the total hepatic blood flow. Despite these limitations, it is clear that the liver is producing most of the endogenous acetate in both ITA and diabetic sheep. Assuming liver and muscle represent the major sources of endogenous acetate production, as is suggested by their enzymatic potential to produce acetate (Knowles et al. 1974), then endogenous acetate represents approximately 26 and $59 \%$ of the total entry rate in ITA and diabetic sheep respectively. The absolute rate of endogenous acetate production remains constant in the 


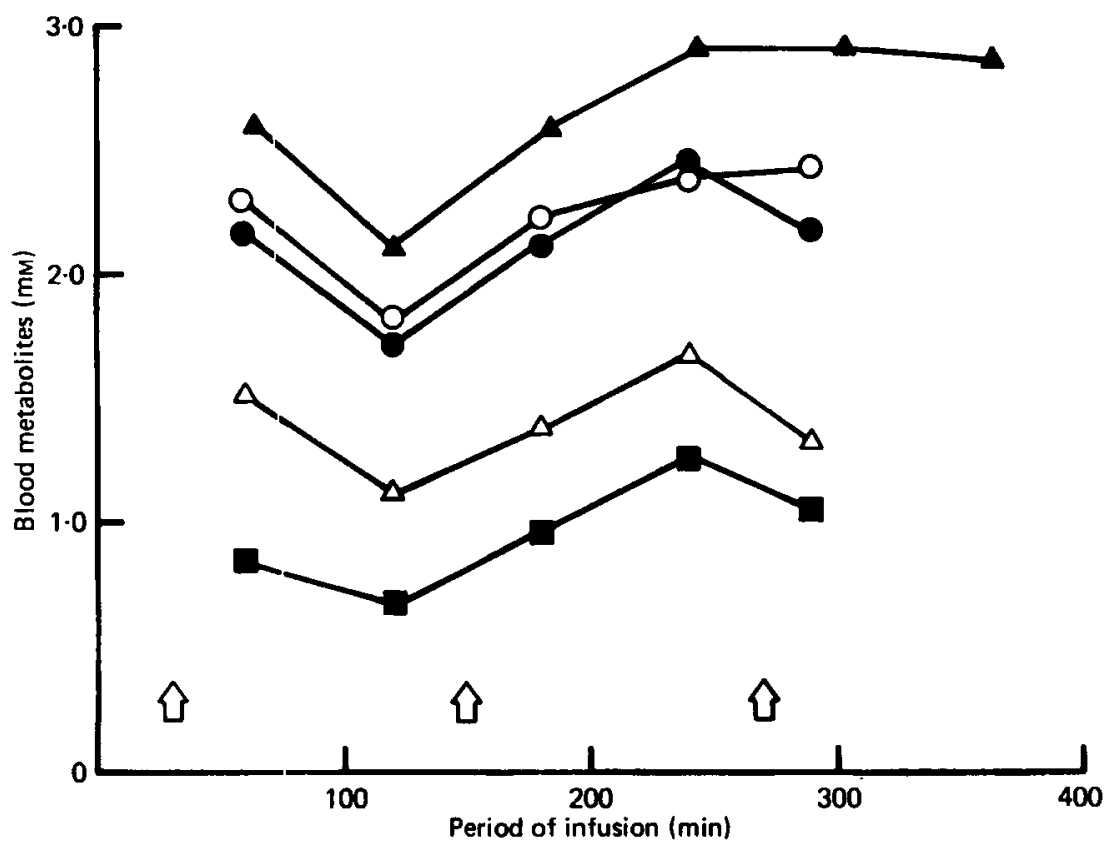

Fig. 2. The concentration of blood metabolites (mM) during the infusion of $\left[\mathrm{U}-{ }^{14} \mathrm{C}\right]$ acetate in an alloxan-diabetic sheep stabilized with insulin (Expt 99). The diet was $1 \mathrm{~kg}$ chopped hay with $100 \mathrm{~g}$ rolled oats fed as twelve individual two hourly rations. Oxygen: (A) $A-V$ across muscle. Acetate: (O) portal venous, $(O)$ hepatic venous. $(\Delta)$, arterial, $(\square)$ muscle venous. $\uparrow$ Time of feeding.

Table 1. Arterial blood concentrations ( $m M$ ) of various metabolites in normal alloxan-diabetic, insulin-stabilized $(I T A)$ and diabetic sheep*

(Mean values with their standard errors; no. of animals in parentheses. For each animal the value taken was the mean of not less than five determinations)

\begin{tabular}{|c|c|c|c|c|c|c|}
\hline \multirow[b]{3}{*}{ Metabolite } & \multicolumn{6}{|c|}{ State of sheep } \\
\hline & \multicolumn{2}{|c|}{ Normal } & \multicolumn{2}{|c|}{ ITA } & \multicolumn{2}{|c|}{ Diabetic } \\
\hline & Mean & $\mathbf{S E}$ & Mean & $\mathbf{S E}$ & Mean & SE \\
\hline $\begin{array}{l}\text { Glucose } \\
\text { Acetate } \\
\text { D(-)3-hydroxybutyrate } \\
\text { Acetoacetate }\end{array}$ & $\begin{array}{l}3.81 \\
1.63 \\
0.38 \\
0.102\end{array}$ & $\begin{array}{l}0.36(5) \\
0.28(7) \\
0.05(4) \\
0.005(3)\end{array}$ & $\begin{array}{l}6.88 \\
1.28 \\
0.49 \\
0.02\end{array}$ & $\begin{array}{l}1.3(5) \\
0.11(5) \\
0.06(5) \\
0.004(4)\end{array}$ & $\begin{array}{l}17 \cdot 1 \\
0 \cdot 31 \\
2 \cdot 2 \\
0.46\end{array}$ & $\begin{array}{l}0.9(4) \\
0.06(4) \\
0.76(4) \\
0.17(4)\end{array}$ \\
\hline
\end{tabular}

- Both normal and alloxan-diabetic sheep stabilized with insulin were given a maintenance ration of $1 \mathrm{~kg}$ chopped hay ( $500 \mathrm{~g}$ lucerne (Medicago sativa); $500 \mathrm{~g}$ cocksfoot (Dactylis glomerata)) with $100 \mathrm{~g}$ rolled oats, fed as twelve individual rations two hourly. ITA sheep were made diabetic by alloxan administration and then controlled with daily insulin admir istration. Diabetic sheep were alloxan-diabetic sheep stabilized with insulin but had not received food or insulin for $36 \mathrm{~h}$. 


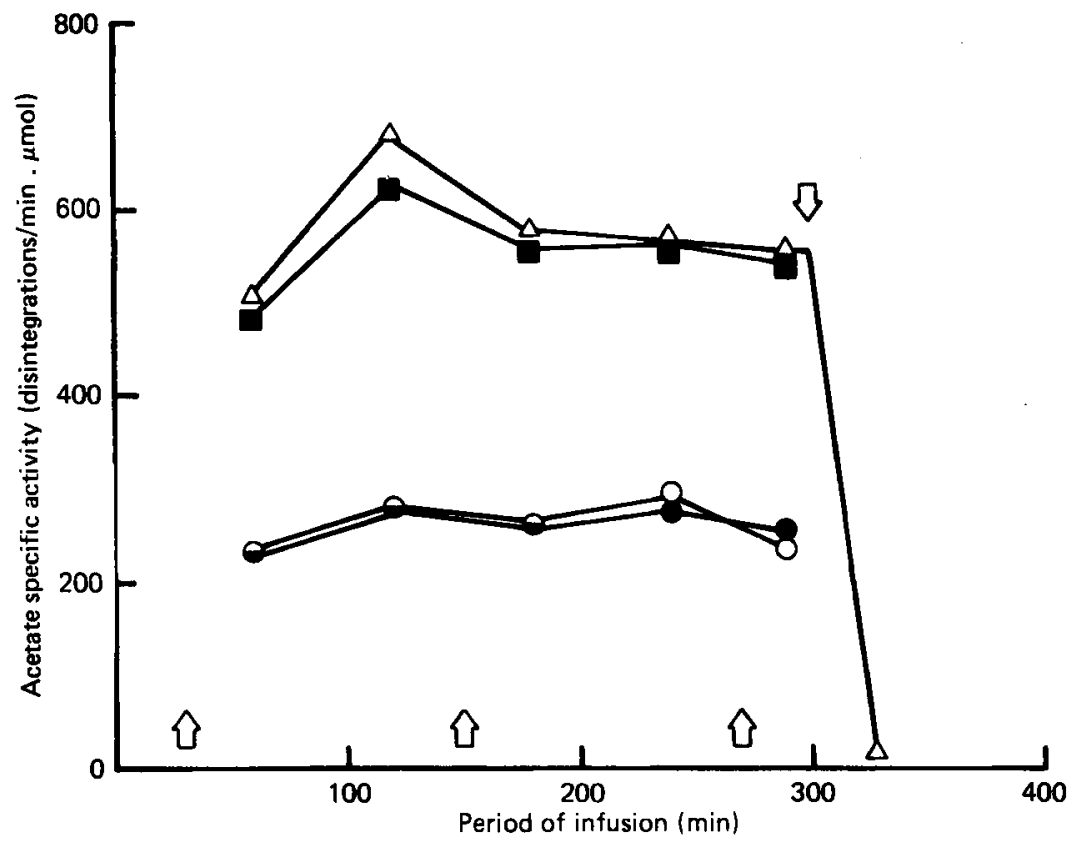

Fig. 3. The specific radioactivity of blood acetate (disintegrations/min per $\mu \mathrm{mol}$ ) during the constant infusion of [U-14 C]acetate (1 420800 disintegrations/min per $\mathrm{min}$ ) into alloxan-diabetic sheep stabilized with insulin (Expt 99). The diet was $1 \mathrm{~kg}$ chopped hay with $100 \mathrm{~g}$ rolled oats fed as twelve individual two hourly rations. Muscle venous $(\square)$, hepatic venous $(\Theta)$, portal venous $(O)$, arterial $(\Delta)$. $\downarrow$ Infusion off, $\uparrow$ Time of feeding.

Table 2. Tissue bloodflow and acetate concentration in arterial $(A)$, muscle venous $(M V)$, portal venous $(P V)$ and hepatic venous $(H V)$ blood in ITA and fasted, diabetic sheep*

(Each blood acetate concentration is the mean of five determinations)

\begin{tabular}{|c|c|c|c|c|c|c|c|c|}
\hline \multirow[b]{2}{*}{ Treatment } & \multirow{2}{*}{$\begin{array}{l}\text { Sheep } \\
\text { no. }\end{array}$} & \multirow{2}{*}{$\begin{array}{l}\text { Body-wt } \\
\text { (kg) }\end{array}$} & \multirow{2}{*}{$\begin{array}{l}\text { Hepatic } \\
\text { blood flow } \\
\text { (1/min) }\end{array}$} & \multirow{2}{*}{$\begin{array}{l}\text { Muscle } \\
\text { blood flow } \\
\text { (1/min per } \\
\text { kg muscle) }\end{array}$} & \multicolumn{4}{|c|}{$\begin{array}{l}\text { Biood acetate } \\
(\mu \mathrm{mol} / \mathrm{ml})\end{array}$} \\
\hline & & & & & $A$ & $M V$ & $P V$ & $H V$ \\
\hline ITA & $\begin{array}{c}1 \\
2 \\
3 \\
4 \\
5 \\
\text { Mean } \\
\text { SEM }\end{array}$ & $\begin{array}{l}50 \\
54 \\
51 \\
44.5 \\
70 \\
54 \\
4\end{array}$ & $\begin{array}{l}2.387 \\
1.863 \\
2 \cdot 150 \\
1.697 \\
2 \cdot 113 \\
2.042 \\
0 \cdot 100\end{array}$ & $\begin{array}{c}\text { ND } \\
0.245 \\
0.249 \\
0.245 \\
0.221 \\
0.240 \\
0.065\end{array}$ & $\begin{array}{l}\mathbf{I} \cdot 01 \\
0.93 \\
0.91 \\
0.94 \\
1.39 \\
1.04 \\
0.09\end{array}$ & $\begin{array}{l}\text { ND } \\
0.61 \\
0.51 \\
0.61 \\
0.97 \\
0.67 \\
0.10\end{array}$ & $\begin{array}{l}1.98 \\
1.54 \\
1.76 \\
\text { ND } \\
2.23 \\
1.88 \\
0.15\end{array}$ & $\begin{array}{l}1.85 \\
1.45 \\
1.66 \\
1.67 \\
2.13 \\
1.76 \\
0.11\end{array}$ \\
\hline Diabetic & $\begin{array}{c}1 \\
2 \\
3 \\
5 \\
\text { Mean } \\
\text { SEM }\end{array}$ & $\begin{array}{r}50 \\
54 \\
51 \\
70 \\
56 \\
5\end{array}$ & $\begin{array}{l}2 \cdot 708 \\
1.480 \\
2 \cdot 179 \\
2 \cdot 239 \\
2 \cdot 152 \\
0 \cdot 200\end{array}$ & $\begin{array}{l}0 \cdot 213 \\
0-201 \\
0.216 \\
0-236 \\
0-216 \\
0 \cdot 100\end{array}$ & $\begin{array}{l}0.32 \\
0.15 \\
0.19 \\
0.41 \\
0.27 \\
0.06\end{array}$ & $\begin{array}{l}0 \cdot 18 \\
0 \cdot 11 \\
0 \cdot 14 \\
0 \cdot 33 \\
0 \cdot 19 \\
0.05\end{array}$ & $\begin{array}{l}0.45 \\
0.27 \\
0.30 \\
0.48 \\
0.38 \\
0.04\end{array}$ & $\begin{array}{l}0.49 \\
0.30 \\
0.31 \\
0.52 \\
0.41 \\
0.06\end{array}$ \\
\hline
\end{tabular}

ND, not determined.

* For procedures for preparation of ITA and fasted, diabetic sheep, see Table 1. 
Table 3. The circulating specific radioactivity of acetate during the constant infusion of [U-14C.]acetate in ITA and fasted, diabetic sheep*

(Each specific radioactivity measurement is the mean of five determinations)

\begin{tabular}{|c|c|c|c|c|c|c|}
\hline \multirow[b]{2}{*}{ Treatment } & \multirow{2}{*}{$\begin{array}{l}\text { Sheep } \\
\text { no. }\end{array}$} & \multirow{2}{*}{$\begin{array}{l}\text { Infusion rate } \\
\text { (disinte- } \\
\text { grations/ } \\
\text { min per min }\end{array}$} & \multicolumn{4}{|c|}{$\begin{array}{c}\text { Specific radioactivity } \\
\text { (disintegrations/min per } \mu \mathrm{mol} \text { ) }\end{array}$} \\
\hline & & & $A$ & $M V$ & $P V$ & $H V$ \\
\hline ITA & $\begin{array}{c}1 \\
2 \\
3 \\
4 \\
5 \\
\text { Mean (\% A) } \\
\text { SEM }\end{array}$ & $\begin{array}{r}711733 \\
796650 \\
1546050 \\
2132633 \\
1420800\end{array}$ & $\begin{array}{l}272 \\
339 \\
937 \\
934 \\
576 \\
100 \\
-\end{array}$ & $\begin{array}{r}\text { ND } \\
333 \\
908 \\
875 \\
556 \\
96 \\
1\end{array}$ & $\begin{array}{r}87 \\
135 \\
313 \\
\text { ND } \\
261 \\
38 \\
3\end{array}$ & $\begin{array}{r}94 \\
130 \\
337 \\
329 \\
260 \\
38 \\
2\end{array}$ \\
\hline Diabetic & $\begin{array}{c}1 \\
2 \\
3 \\
5 \\
\text { Mean }(\% A) \\
\text { SEM }\end{array}$ & $\begin{array}{r}737833 \\
1188450 \\
1005400 \\
1423300\end{array}$ & $\begin{array}{c}1165 \\
2641 \\
2742 \\
1986 \\
100 \\
-\end{array}$ & $\begin{array}{r}1106 \\
2166 \\
1852 \\
1742 \\
83 \\
6\end{array}$ & $\begin{array}{r}635 \\
901 \\
1122 \\
1244 \\
48 \\
6\end{array}$ & $\begin{array}{r}446 \\
807 \\
1082 \\
1182 \\
42 \\
6\end{array}$ \\
\hline
\end{tabular}

ND, not determined.

- For procedures for preparat:on of alloxan-diabetic, insulin-stabilized (ITA) and fasted. diabetic sheep, see Table 1.

Table 4. Summary of acetate utilization and production in tissues of sheep*

(Mean values with their stancard errors are for four animals. The results are means of the individual animals presented in Tables 2 and 3)

\begin{tabular}{|c|c|c|c|c|c|c|c|c|c|c|c|c|}
\hline \multirow[b]{4}{*}{ Tissue } & \multicolumn{10}{|c|}{ Treatment } & & \\
\hline & \multicolumn{6}{|c|}{ ITA } & \multicolumn{6}{|c|}{ Diabetic } \\
\hline & \multicolumn{3}{|c|}{$\begin{array}{l}\text { Net utilization } \\
\text { (mmol/h) }\end{array}$} & \multicolumn{3}{|c|}{$\begin{array}{l}\text { Production } \\
\text { (mmol/h) }\end{array}$} & \multicolumn{3}{|c|}{$\begin{array}{l}\text { Net utilization } \\
(\mathrm{mmol} / \mathrm{h})\end{array}$} & \multicolumn{3}{|c|}{$\begin{array}{l}\text { Production } \\
\text { (mmol/h) }\end{array}$} \\
\hline & Mean & SE & $\begin{array}{c}\% \\
\text { Total }\end{array}$ & Mean & SE & $\begin{array}{c}\% \\
\text { Total }\end{array}$ & Mean & SE & Total & Mean & SE & $\stackrel{\circ}{\circ} \stackrel{0}{0}$ \\
\hline $\begin{array}{l}\text { Muscle } \\
\text { Gut } \\
\text { Liver }\end{array}$ & $\begin{array}{l}74 \\
34 \\
23\end{array}$ & $\begin{array}{l}4 \\
4 \\
3\end{array}$ & $\begin{array}{l}54 \\
25 \\
17\end{array}$ & $\begin{array}{r}3 \\
119 \\
31\end{array}$ & $\begin{array}{c}0.6 \\
15 \\
3\end{array}$ & $\begin{array}{r}3 \\
88 \\
23\end{array}$ & $\begin{array}{r}18 \\
8 \\
8\end{array}$ & $\begin{array}{l}4 \\
1 \\
3\end{array}$ & $\begin{array}{l}60 \\
25 \\
25\end{array}$ & $\begin{array}{r}5 \\
19 \\
14\end{array}$ & $\begin{array}{l}1 \\
3 \\
5\end{array}$ & $\begin{array}{l}15 \\
59 \\
44\end{array}$ \\
\hline Sum & 131 & - & 96 & 153 & - & 114 & 34 & - & 110 & 38 & - & 118 \\
\hline Whole animal & 136 & 10 & 100 & 136 & 10 & 100 & 32 & 5 & 100 & 32 & 5 & 100 \\
\hline
\end{tabular}

* For procedures for preparation of alloxan-diabetic, insulin-stabilized (ITA) and fasted. diabetic sheep. see Table 1 .

muscle of both ITA and diabetic sheep, but in the liver the rate may decline in diabetic animals $(P=0.05)$. Hepatic acetate production and ketogenesis are not related quantitatively since the ratio, carbon, released by the liver as acetate: that released as ketones was 2 (i.e. $62 \pm 6: 30 \pm 12 \mathrm{mmol} / \mathrm{h}$ ) in f:d and $0 \cdot 12$ (i.e. $28 \pm 10: 240 \pm 32 \mathrm{mmol} / \mathrm{h}$ ) in ketotic sheep.

All tissues studied utilized appreciable fractions of the total acetate entry rate, with the 
Table 5. Acetate production in sheep tissues*

(Mean values with their standard errors; no. of animals in parentheses)

\begin{tabular}{|c|c|c|c|c|c|c|c|c|c|c|c|}
\hline \multirow{3}{*}{$\begin{array}{r}\text { Treatment } \\
\text { Tissue }\end{array}$} & \multirow{3}{*}{$\ldots$} & \multicolumn{4}{|c|}{$\begin{array}{c}\begin{array}{c}\text { Maximum contribution of } \\
\text { acetate to oxygen consumption } \\
(\%) \dagger\end{array} \\
\end{array}$} & \multirow{2}{*}{\multicolumn{2}{|c|}{$\begin{array}{c}\text { Contribution } \\
\text { of acetate } \\
\text { to carbon } \\
\text { dioxide } \\
\text { production } \\
(\%) \\
\text { ITA }\end{array}$}} & \multirow{2}{*}{\multicolumn{2}{|c|}{$\begin{array}{l}\text { Proportion } \\
\text { utilized } \\
\text { acetate } \\
\text { directly } \\
\text { oxidized } \\
\text { ITA }\end{array}$}} & \multirow{2}{*}{\multicolumn{2}{|c|}{$\begin{array}{l}\text { Direct } \\
\text { oxidation } \\
\text { calculation } \\
\text { equilibrium } \\
\text { method: } \\
\text { area method }\end{array}$}} \\
\hline & & \multicolumn{2}{|c|}{ ITA } & \multicolumn{2}{|c|}{ Diabetic } & & & & & & \\
\hline & & Mean & $\mathbf{S E}$ & Mean & $\mathrm{SE}$ & Mean & SE & Mean & $\mathbf{S E}$ & Mean & $\mathbf{S E}$ \\
\hline Whole animal & (5) & 39 & 3 & 10 & 2 & 26 & 1 & 78 & 4 & 0.91 & 0.03 \\
\hline & (4) & 50 & 5 & 13 & 3 & 36 & 3 & 77 & 12 & 0.75 & 0.12 \\
\hline Liver & (3) & 29 & 5 & 7 & 2 & 3 & 1 & 6 & 2 & ND & - \\
\hline Muscle & (5) & 35 & 2 & 6 & 2 & 29 & 6 & 78 & 13 & 0.62 & 0.16 \\
\hline
\end{tabular}

ND, equilibrium method not determined.

* For procedures for preparation of alloxan-diabetic, insulin-stabilized (ITA) and fasted, diabetic sheep, see Table 1.

$\dagger$ Mean respiratory $\mathrm{O}_{2}$ consumption (mmol/h per kg body-weight) was 12.5 (respiratory quotient (RQ) 1.13 ) and $12 \cdot 1$ (RQ $0 \cdot 77)$ in ITA and diabetic sheep respectively.

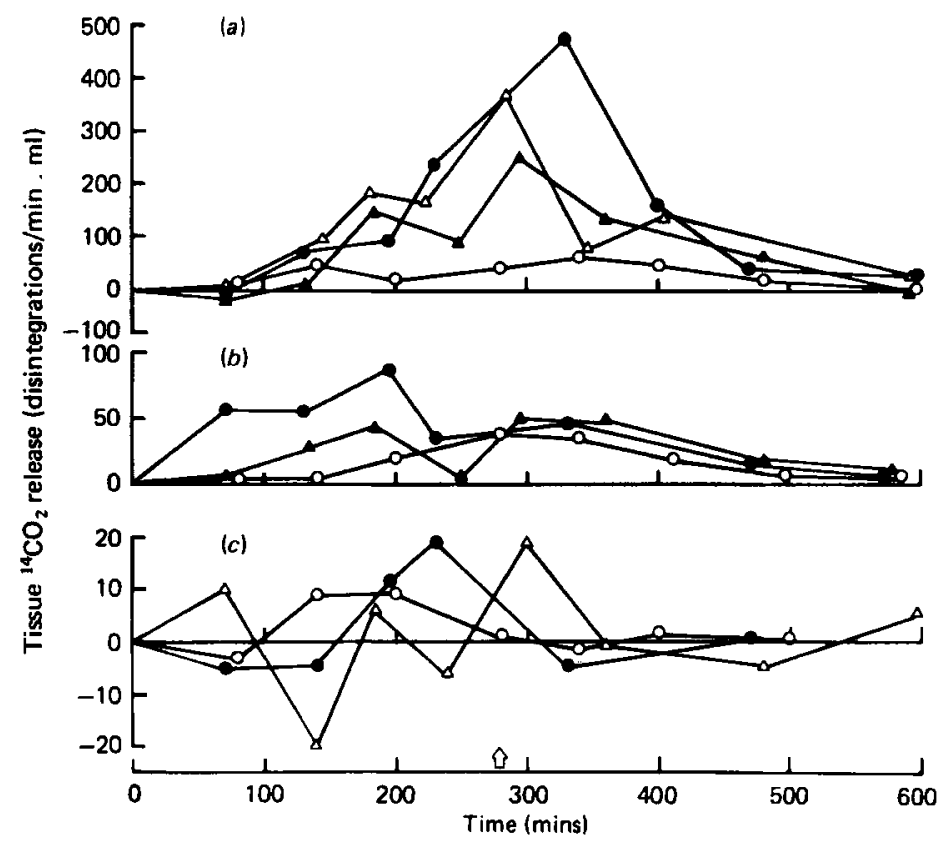

Fig. 4. The release of ${ }^{14} \mathrm{CO}_{2}$ from (a) muscle, (b) gut and (c) liver during the constant infusion of [U-14 C]acetate into alloxan-diabetic sheep stabilized with insulin. The diet was $1 \mathrm{~kg}$ chopped hay with $100 \mathrm{~g}$ rolled oats fed as twelve individual two hourly rations. Expts $59(0), 68(\Theta), 90(\triangle), 99(\Delta)$. Tissue release of ${ }^{14} \mathrm{CO}_{2}$ was calculated as veno-arterial ${ }^{14} \mathrm{CO}_{2}$ difference (disintegrations/min per $\mathrm{ml}$ ) except for the liver where the arterial concentration was replaced by $\left(0.2 \times\left[{ }^{14} \mathrm{CO}_{2} \mathrm{~A}\right]+0.8\left[{ }^{14} \mathrm{CO}, \mathrm{PV}\right]\right.$, where $\left[{ }^{14} \mathrm{CO}_{2} \mathrm{PV}\right]$ and $\left[{ }^{14} \mathrm{CO}_{2} \mathrm{~A}\right]$ are the radioactive concentrations of $\mathrm{CO}_{2}$ in portal venous and arterial blood respectively (disintegrations/min per $\mathrm{ml}$ ). 
relative proportions of the total entry utilized by each tissue being similar in both ITA and diabetic sheep. The splanch nic tissues accounted for as much acetate as muscle (42-50\%) and the sum of all tissues accounted for $85-98 \%$ of the acetate entry rate. Acetate utilization in all tissues was linearly relited to arterial supply (or weighted arterial/portal (A/P) supply for the liver) so that if $y$ is gross acetate utilization $(\mathrm{mmol} / \mathrm{h})$ and $x$ is the arterial plasma acetate (or weighted A/P for the liver, mM) then for the gut: $y=30.3 x \times 0.7\left(r^{2} 0.92 ; F_{6}^{1}\right.$ $32 ; P \simeq 0.001)$; for the liver: $y=11.9 x+3.0\left(r^{2} 0.86 ; F_{6}^{1} 16.8 ; P \simeq 0.006\right)$; for the muscle $(10 \mathrm{~kg}): y=3.83 x+0.363\left(r^{2} 0.93 ; F_{6}^{1} 39.8 ; P<0.001\right)$.

\section{Acetate oxidation in sheep}

The maximum potential and actual oxidation of acetate in the sheep of this study is shown in Table 5. Potentially acetate can supply approximately $40 \%$ of the energy needs of fed sheep. However, not all is directly oxidized; only $26 \%$ of the respiratory $\mathrm{CO}_{2}$ is derived from acetate. The two methods of calculating whole animal direct oxidation differ so that computing oxidation using the equilibrium calculation (see, p. 101) underestimates oxidation by approximately $10 \%$.

Acetate is potentially a significant fuel for all tissues studied, theoretically accounting for $30-50 \%$ of the $\mathrm{O}_{2}$ consumption. In the gut and muscle most of the acetate is oxidized to $\mathrm{CO}_{2}$, while in the liver apparently large quantities of acetate enter non-oxidative pathways. Release of ${ }^{14} \mathrm{CO}_{2}$ by the tissues is shown in Fig. 4. While significant release is obvious for the muscle and gut there is no significant release of ${ }^{14} \mathrm{CO}_{2}$ by the liver. This latter result is equivocal since the precisicin of measurement is lowered due to the necessity of three measurements of ${ }^{14} \mathrm{CO}_{2}$ radioactivity $[A, P V$ and hepatic venous $(H V)]$ for each point in Fig. 4(c) and relatively low $\mathrm{CO}_{2}$ production by the liver (hepatic RQ $0.76 \pm 0.04$ ). The limit of sensitivity would suggest that acetate could contribute $<20 \%$ of the hepatic $\mathrm{CO}_{2}$ production. The method used to calculate tissue oxidation greatly affects the resultant value. Even more than in the calculation of acetate oxidation in the whole animal the equilibrium method consistently underestimates oxidation. This is probably related to the slow rate of $\mathrm{CO}_{2}$ equilibration in tissues. 'Thus in muscle, ${ }^{14} \mathrm{CO}_{2}$ release was not detectable after $60 \mathrm{~min}$ of [U-14 C]acetate infusion ard sometimes not after $120 \mathrm{~min}$.

\section{DISCUSSION}

This work sought to define acetate metabolism as fully as possible by extending the techniques developed by Be::gman \& Wolff (1971). Our results for gut metabolism are essentially similar to these authors'. In their study $29 \%$ of the digestible energy intake appears as acetate and $30 \%(29 \%$ in this study) of the absorbed acetate is directly utilized by the gut. Results for the liver differ since a significant utilization and production of acetate were measured in this study.

\section{Acetate supply}

It is clear that food intake in this study is the major determinant of blood acetate concentration. Even in lightly starved diabetic animals the endogenous release did not increase. Such results imply that blood acetate could be a useful index of nutrition although it is derived from two sources (endogenous and exogenous). This is because we find endogenous secretion is relatively stable, as also did Bergman \& Wolff(1971). Consequently blood acetate concentration zould be considered as a possible component of a metabolic profile test (Payne et al. 197()).

There is some evidence that endogenous acetate secretion in vivo can fluctuate. Annison et al. (1974) compared the entry rate of acetate into the rumen and circulation, and concluded that endogenous acetate secretion was minimal in lactating dairy cows given a 
high-concentrate diet. Another interpretation of their results is possible however, if in the cow, as we have currently found for the sheep, the liver may use acetate. Isotope-dilution techniques assume that the acetate leaving the circulation has a uniform specific radioactivity but acetate utilized by the liver has a specific activity $50 \%$ less than in arterial blood. Thus, in cows on normal diets, if we use the calculation of Annison \& Lindsay (1962) acetate entry is overestimated by approximately $10 \%$ and apparent endogenous acetate production may seem large. Any factors influencing acetate utilization by the liver will change the apparent entry rate of acetate into the circulation. The high diet used by Annison et al. (1974) increased the molar proportion of propionic acid in the rumen and if this was reflected in an increased portal propionate concentration then acetate utilization by the liver may have been depressed, since the utilization of acetate by the liver may be depressed by propionate (Leng \& Annison, 1963; Smith, 1971). In these circumstances, apparent acetate entry into the circulation would not be overestimated, and might more closely agree with the acetate entry rate in the rumen. Although speculative, this consideration shows the caution which should be attached to observations comparing rumen and circulating acetate entry rate.

The means of control of acetate output by tissues, particularly the liver, has not been determined in this study. Factors promoting ketogenesis do not proportionally affect acetate release. One factor contributing to this may be that sources of acetate production in fed and fasted animals differ. Thus in fed sheep, acetate may be formed from butyrate (Annison et al. 1963) or other VFA; ethanol (Buckley \& Williamson, 1977); or possibly amino acids as well as NEFA: while in fasting, NEFA are the major precursors (Palmquist, 1972). The results of the present study agree with those of Snoswell et al. (1978) who used lactating cows. Both studies suggest that acetate release is not primarily determined by NEFA flux or the ratio, acetyl CoA:CoA ('acetyl pressure') which are known to increase in diabetic sheep (Snoswell \& Koundakjian, 1972; Jarrett et al. 1974).

\section{Acetate utilization}

All the tissues studied used substantial amounts of acetate. Bergman \& Wolff (1971) appreciated that acetate utilization by the gut could be due to a multiplicity of factors including lipogenesis, oxidation by smooth muscle, net conversion to other compounds, simple exchange or even possibly diffusion into the lumen of the digestive tract. They suggested that much acetate was used for lipogenesis, but the results of the present study show rather that it is largely oxidized.

The origin of the acetate oxidized however is uncertain since acetate could be utilized in the gut from the arterial supply and in the rumen from absorbed acetate as well (Stevens, 1970). The contribution of acetate to $\mathrm{O}_{2}$ consumption by the gut on the assumption the ${ }^{14} \mathrm{C}$-labelled acetate extracted is all oxidized (see Table 5) is maximal if only arterial acetate is utilized (see Bergman, 1975) but could be greater if there is also a contribution from absorbed acetate. The contribution of acetate to oxidative metabolism in the gut on the basis of ${ }^{14} \mathrm{CO}_{2}$ output (Table 5) takes account of both sources of acetate, but is an underestimate because there is considerable $\mathrm{CO}_{2}$ exchange across the rumen wall. Ash \& Dobson (1963) found that for every $1 \mathrm{~mol}$ of acetate absorbed, $0.5 \mathrm{~mol} \mathrm{CO} 2$ entered the rumen from the blood. If this is true for all VFA then the ${ }^{14} \mathrm{CO}_{2}$ production by gut tissue from utilized [U-14 C]acetate is underestimated by approximately $20 \%$; this would mean that most of the utilized acetate is directly oxidized.

The hepatic utilization of acetate is within the known enzymatic capacity of the acetyl CoA synthase (EC 6.2.1.1) reaction (Knowles et al. 1974) and so is clearly not unrealistic. Nevertheless further work is desirable to verify the apparent low level of oxidation suggested in this study. Acetate does contribute to non-oxidative pathways, i.e. 3-HB synthesis in fed sheep (Annison et al. 1963) and also non-essential amino acid synthesis (Holdsworth et al. 1964). Fatty acid synthesis is minimal in the ruminant liver (see Bauman \& Davis, 1975). 
Acetate is clearly an important nutrient for muscle in fed sheep since approximately $30 \%$ of the energy metabolisrn is derived from this source. It is largely oxidized, although some acetate may be used for intermuscular fat synthesis. Emphasis must be given to the methodology of measuring oxidation since if an equilibrium ${ }^{14} \mathrm{CO}_{2}$ production by muscle was assumed then only approximately $48 \%$ of the acetate would apparently by oxidized. Bell \& Thompson (1979) who used a similar technique to measure NEFA oxidation by skeletal muscle assumed a steady-state ${ }^{14} \mathrm{CO}_{2}$ release by the steer hind-limb within $2-3 \mathrm{~h}$ of ${ }^{14} \mathrm{C}$-labelled NEFA infusion. Such a study must be interpreted cautiously on the basis of the results presented in this study.

In conclusion, circulating acetate concentration is dominated substantially by the dietary formation of acetate. Similar conclusions have been drawn even for non-ruminant animals such as the rat (Buckley \& Williamson, 1977). Since circulating acetate concentration and entry rate are generally linearly related, acetate may represent a useful metabolite to help predict the nutritional state of a grazing ruminant animal.

\section{REFERENCES}

Annison, E. F. \& Armstrong, D. G. (1970). In Physiology and Digestion and Metabolism in the Ruminant, p. 422 [A. T. Phillipson, editor]. Newcastle-upon-Tyne: Oriel Press.

Annison, E. F., Bickerstaffe, P.. \& Linzell, J. L. (1974). J. agric. Sci., Camb. 82, 87.

Annison, E. F., Brown, R. A., Leng, R. A., Lindsay, D. B. \& West, C. E. (1967). Biochem. J. 104, 135.

Annison, E. F., Leng, R. A., I.indsay, D. B. \& White, R. R. (1963). Biochem. J. 88, 248.

Annison, E. F. \& Lindsay, D. B. (1961). Biochem. J. 78, 777.

Annison, E. F. \& Lindsay, D. B. (1962). Biochem. J. 85, 474.

Annison, E. F. \& White, R. R. (1962). Biochem. J. 84, 546.

Ash, R. W. \& Dobson, A. (19.53). J. Physiol., Lond. 169, 39.

Ballard, F. J., Hanson, R. W. \& Kronfeld, O. S. (1969). Fedn Proc. Fedn Am. Socs Exp. Biol. $28,218$.

Bauman, D. E. \& Davis, C. L. (1975). In Digestion and Metabolism in the Ruminant, p. 496 [1. W. McDonald and

A. C. I. Warner, editors]. Armidale, New South Wales: The University of New England Publishing Unit.

Bell, A. W. \& Thompson, G. E. (1979). Am. J. Physiol. 237, E309.

Bergman, E. N. (1975). In Dige.ition and Metabolism in the Ruminant, p. 292 [I. W. McDonald and A. C. I. Warner, editors]. Armidale, New South Wales: The University of New England Publishing Unit.

Bergman, E. N. \& Wolff, J. E. (1971). Am. J. Physiol. 221, 586.

Bradley, S. E., Ingelfinger, F. .J., Bradley, C. P. \& Curry, J. J. (1945). J. clin. Invest. 24, 890.

Buckley, B. M. \& Williamson, D. H. (1977). Biochem. J. 166, 539.

Costa, N. D., Mclntosh, G. H. \& Snoswell, A. M. (1976). Aust. J. biol. Sci. 29, 33.

Domanski, A., Lindsay, D. B. \& Setchell, B. P. (1974). J. Physiol., Lond. 242, 28 P.

Hinks, N. T., Miller, S. C. \& S Setchell, B. P. (1966). Analyt. Biochem. 17, 551.

Holdsworth, E. S., Neville, E., Nader, C., Jarrett, I. G. \& Filsell, O. H. (1964). Biochim. biophys. Acta 86, 240.

Jarrett, I. G., Filsell, O. H. \& 3allard, F. J. (1974). Horm. Metab. Res. Suppl. 4, 111.

Katz, M. L. \& Bergman, E. N. (1969a). Am. J. vet. Res. 30, 655.

Katz, M. L. \& Bergman, E. N (1969b). Am. J. Physiol. 216, 946.

Knowles, S. E., Jarrett, I. G., Filsell, O. H. \& Ballard, F. J. (1974). Biochem. J. 142, 401.

Leng, R. A. \& Annison, E. F. (1963). Biachem. J. 86, 319.

Lindsay, D. B. (1978). In Occasional Publications of the British Society of Animal Production, no. 1, p. 99. BSAP, Milton Keynes.

Linzell, J. L. (1974). In Lactation, A Comprehensive Treatise, vol. 1, p. 143 [B. L. Larson and V. R. Smith, editors]. New York and London: Academic Press.

McCrae, J. C., Wilson, S. \& Milne, J. A. (1978). Proc. Nutr. Soc. 37, 16 A.

MAFF (1976). Energy allowances and feeding systems for ruminants, Technical Bulletin 33, Ministry of Agriculture, Fisheries and Food. London: H.M. Stationery Office.

Neill, A. R., Grime, D. W., Sinoswell, A. M., Northrop, A. J., Lindsay, D. B. \& Dawson, R. M. C. (1979). Biochem. J. 180, 559.

Palmquist, D. L. (1972). J. Nutr. 102, 1401.

Palsson, H. \& Verges, J. B. (1952). J. agric. Sci., Camb. 42, 1.

Pappenheimer, J. R. \& Setchell, B. P. (1972). J. Physiol., Lond. 226, 48P.

Paterson, J. Y. F. \& Harrison, F. A. (1972). J. Endocr. 55, 338.

Payne, J. M., Dew, S. M., Manson, R. \& Faulks, M. (1970). Vet. Rec. 87, 150.

Seufert, C. D., Graf, M., Jansı), G., Kuhn, A. \& Söling, H. D. (1974). Biochim. Biophys. Res. Comm. 57, 901

Smith, R. A. M. (1971). Biochem. J. 124, 877. 
Snoswell, A. M., Costa, N. D., McLean, J. G., Baird, G. D., Lomax, M. A. \& Symonds, H. A. (1978). J. Dairy Sci. 45, 331.

Snoswell, A. M. \& Koundakjian, P. P. (1972). Biochem. J. 127, 133.

Stevens, C. E. (1970). In Physiology of Digestion and Metabolism in the Ruminant, p. 438 [A. T. Phillipson, editor]. Newcastle-upon-Tyne: Oriel Press.

Thompson, G. E., Gardner, J. W. \& Bell, A. W. (1975). Q. Jl expt. Physiol. 60, 107.

Werner, W., Rey, H. G. \& Wielinger, H. (1970). Z. Analyt. Chem. 252, 224.

Williamson, D. H., Mellanby, J. \& Krebs, H. A. (1962). Biochem. J. 82, 90.

Zierler, K. L. (1961). J. clin. Invest. 40, 2111. 